\title{
TITLE:
}

\section{SEA-STARS OF SETO AND ADJACENT WATERS}

$\operatorname{AUTHOR}(\mathrm{S})$ :

Hayashi, Ryoji

\section{CITATION:}

Hayashi, Ryoji. SEA-STARS OF SETO AND ADJACENT WATERS.

PUBLICATIONS OF THE SETO MARINE BIOLOGICAL LABORATORY 1952, 2(2): 143-159

ISSUE DATE:

1952-10-05

URL:

http://hdl.handle.net/2433/174682

RIGHT: 


\title{
SEA-STARS OF SETO AND ADJACENT WATERS*
}

\author{
RYOJI HAYASHI
}

Biological Insiitute, Faculty of Liberal Arts, Toyama University

With Plate VIII and 8 Text-figures

The present writer $(1938 \mathrm{c})$ reported the sea-stars occurring in the vicinity of the Seto Marine Biological Laboratory. Recently he could further examine an additional collection of sea-stars obtained from the adjacent waters through the kindness of Dr. H. UTiNomi. One of them seems to be new to science, and three of them have not previously been recorded in Japanese waters, which are tropical forms. Here follows a list of the species newly examined by the writer. The asterisks indicate species new to Japan.

Mediaster brachiatus Goto

Hippasteria imperialis GoTo

*Lithosoma japonica n. sp.

* Anthenoides epixanihus (FisHER)

* Nardoa tuberculata GrAY

Ophidiasier cribrarius LÜTKEN.

Henricia Ohshimai forma acutispina HAYASHI

Henricia pacifica HaYASH

Henricia pachyderma HAYASHI

Solaster Uchidai HAYASHI

* Coronaster volsellatus (SLADEN)

The following 37 forms of sea-stars, thus, will be noted in the vicinity of the Seto Marine Biological Laboratory.

Ord. Phanerozonia

Fam. Astropectinidae

1) Astropecten scoparius Valenciennes: Hayashi (38c)

2) Astropecten polyacanthus $\mathrm{V}_{\mathrm{U}} \mathrm{LLER}$ et TroscheI: HAYASHI ('38c)

3) Astropecien kagoshimensis DE LoRIOL: HAYASHI ('38c)

* Contributions from the Seto Marine Biological Laboratory, No. 181.

Publ. Seto Mar. Biol. Lab., II (2), 1952. (Article 9) 
4) Astropecten latespinous MEISSNER: HAYASHI ('38c)

5) Persephonaster setoensis HAYASHI: HaYASHI ('38c)

Fam. Luidiidae

6) Luidia quinaria v. Martens: Hayashi (38c)

7) Luidia miculala Müller et Troschel: Hayashi ('38c)

Fam. Goniasteridae

8) Mediaster brachiatus Gото

9) Lithosoma japonica n. sp.

10) Anthenoides epixanthus (FISHER)

11) Hippasteria imperialis GoTo

Fam. Oreasteridae

12) Asterodiscus Hiroi Hayashi : Hayashi ('38c)

Fam. Linckiidae

13) Fromia indica Perrier: Hayashi ('38c)

14) Fromia monilis PERRIER: HAYASHI ('38c)

15) Nardoa tuberculata GRAY

16) Nardoa frianti KoeHLER: HAYASHI (38c)

17) Certonardoa semiregularis (MÖLLER et TROSCHEL): HAYASHI ('38c)

18) Ophidiaster lorioli FISHER: HAYASHI ('38c)

19) Ophidister cribrarius LÜTKEN

20) Leiaster grandis HAYASHI: HAYASHI ('38c)

21) Linckia guildingii GraY: HaYASHI ('38c)

Ord. Spinulos A

Fam. Asterinidae

22) Asterina batheri Goto: HAYASHI ('38c, '40)

23) Asterina coronata forma japonica HaYASHI : HAYASHI ('38c, '40)

24) Asterina pectinifera Müller et Troschel: Hayashi ('38c, '40)

Fam. Echinasteridae

25) Henricia Ohshimai forma acutispina HAYASHI: HAYASHI ('40)

26) Henricia pacifica Hayashi: Hayashi ('40)

27) Henricia pachyderma HAYASHI

Fam. Mithrodidae

28) Mithrodia clavigera (LAMARCK): HAYASHI ('38c, '40)

Fam. Solasteridae

29) Solaster Uchidai HAYASHI

Fam. Pterasteridae

30) Pteraster tesselatus IVES: HAYASHI ('38c, '40)

31) Pteraster jordani FISHeR: HAyAshi ('40)

32) Diplopteraster multipes (SARs): Hayashi ('40) 
33) Hymenaster glaucus SLADEN : HaYASHI ('40)

Ord. Forcipulata

Fam. Zoroasteridae

34) Cnemidaster wyvillii Sladen; HaYASHI ('43)

Fam. Asteriidae

35) Coronaster volsellatus (SLADEN)

36) Coscinasterias acutispina. (STIMPSON): HAYASHI ('38c, '43)

37) Asterias amurensis LüTKen: HAYASHI ('38c, '43)

The writer must express herein his cordial thanks to Dr. H. UTINom, Deputy Director of the Seto Marine Biological Laboratory, for his kindness placing the specimens at the writer's disposal.

\title{
DESCRIPTIONS OF SPECIES
}

\author{
Mediaster brachiatus GoTo
}

(P1. VIII, Figs. 3, 4)

Mediaster brachiatus: GOTO, 1914, p. 354, pl. 9, figs, 142-152; pl. 10, figs. 153-155.

Four specimens belonging to the present genus, Mediaster, were examined. These specimens generally agree in essential particulars with the present species. The measurements and localities are as follows:

$\begin{array}{ccll}\mathrm{R} & \mathrm{r} & \mathrm{R}: \mathrm{r} & \text { Localities } \\ 30 \mathrm{~mm} & 11 \mathrm{~mm} & 2.7 & \text { Kii-oshima } \\ 46 \mathrm{~mm} & 17 \mathrm{~mm} & 2.7 & \text { Off Minabe, 100- } \\ \cdots & & & 200 \mathrm{~m} \text { in depth } \\ 52 \mathrm{~mm} & 18 \mathrm{~mm} & 2.9 & \text { Kii-oshima } \\ 54 \mathrm{~mm} & 21 \mathrm{~mm} & 2.5 & \text { Off Minabe, } 100 \\ & & & 200 \mathrm{~m} \text { in depth }\end{array}$

Body nearly flattened, rays 5 in number. Interbrachial arcs wide and round. Rays gradually tapering toward the tip, rather slender. Dorsal paxillae fairly large, distinct, the large being in the radial zones, thence decreasing in size toward the side of body. A triangular area with smaller paxillae can be seen in each interradial zone. Median radial paxillae arranged in regular series, scarcely different from the adradials in size and form. The median radial series reaches the terminal plate, both the adradials nearly the very tip of ray. The paxillae are coronal in form, the large each with 6 to 13 blunt spinelets on the periphery of tabulum and 1 to 5 in the centre. In small paxillae the central spinelets are absent, each with 4 to 6 peripheral spinelets. A 
large number of the paxillae bear bivalvate pedicellariae on the edge or near the centre, 1 for a paxilla. The pedicellariae are much higher than wide and larger than the spinelets, the inner faces of the jaws slightly concaved.

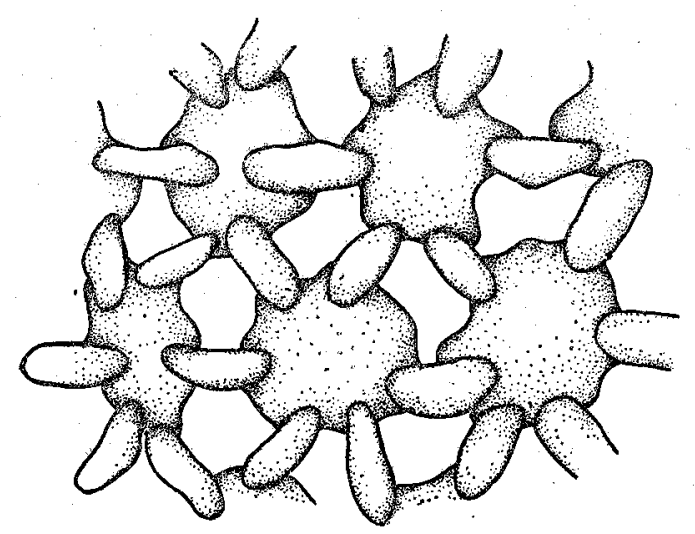

Fig. 1. Mediaster brachiatus: Dorsal sktleton near the arm base, viewed from coelomic side, $25 \times$.

Dorsal plates well spaced, cylindrical in form, roundish or elliptical in outline. These are each connected by small internal ossicles. Papulae one for each papular area, but rarely two. These are absent from the area adjacent to marginal plates.

Superomarginal plates distinct, confined to the side wall of body, 36-37 in number. These are higher than long in the interradial portion of ray, then decreasing in height toward the tip of ray. The superomarginals are covered with coarse granules evenly spaced and about uniform in size. The pedicellariae on the superomarginals are not described by Goтo ('14), but in the writer's specimens there are found a few bivalvate pedicellariae in the interrabial portion, mostly 1 for a plate. These are onot cnspicuous but slightly larger and longer than the granules. Inferomarginal plates generally coincident with the superomarginals in size and form, forming a border to the ventral surface of body. The granulation is generally similar to that of the superomarginals, but those near the lower edge are slightly coarser. Bivalvate pedicellariae found as in the superomarginals, but not numerous.

Ventrolateral area large, and the plates are arranged regularly in series parallel to the furrow, the innermost series extending about two thirds the length of ray. The plates are slightly convex and armed with 5 to 13 spaced granule-like spinelets somewhat pyramidal form. The ventrolaterals often bear trivalvate pedicellariae in the innermost series, the jaws being longer 
and more slender than those of dorsal or marginal pedicellariae.

Adambulacral plates rather quadrate in form, each armed with 3 rows of spines. The first row consists of 7 remarkable, straight, subequal, strongly compressed, round-tipped spines, and the adoral one is slightly shorter than the others. The spines are variable in number, ranging from 5 to 8 in specimens, but mostly 6 or 7 . The second row is composed of mostly 5 (4-6) spines, similar in form to those of the first row, but slightly shorter. In a number of the plates are found pedicellariae with 3 to 5 jaws. The pedicellariae are similar to the spines in appearance, taking the place of the latter, one for a plate. The third row consists of 5 (4) spines similar to those of ventrolateral plates. The adambulacral armature may be shown by the for mula 6 or $7(5-8)-5(4-6)-4(3-5)$. Mouth plates elongated triangular in form, each with 10 to 11 stout strongly compressed furrow spines. On the ventral surface there are 7 or 8 spines along the suture line of the plates and 5 or 6 spines facing the first adambulacral plate.

Madreporite situated nearer the centre of disc than the margin.

Loc. Off Minabe, depth $100-200 \mathrm{~m}$ and Kii-oshima

\section{Hippasteria imperial is GoTO}

(P1. VIII, Figs. 1, 2)

Hippasteria impsrialis : GOTO, 1914, p. 338, pl. 12, figs. 178-193.

A single specimen of the genus, Hippasteria, was examined, which measures $43 \mathrm{~mm}$ in $\mathrm{R}, 24 \mathrm{~mm}$ in $\mathrm{r}$. The example is referred to a young form of the present species, H. imperialis. Goto's description is based upon a single large specimen measuring $124 \mathrm{~mm}$ in $R, 71 \mathrm{~mm}$ in $\mathrm{r}$, which is obtained from off Misai, defth $640 \mathrm{~m}$. The cescription of the writer's specimen is as follows:

Body stellato-pentagonal in form, flat and depressed. Interbrachial arcs fairly rounded, not nearly straight as stated by Goro (14). Dorsal plates closely set, unequal in size, the larger ones being roundish or elliptical in form and slightly convex. The large plates are arranged in rather regular series. The primary radial and interradial plates of apical system are rather easily distinguishable from the secondary ones. These are slightly larger than the others. The small intermediate plates interpolated between the large plates have a tendency of surrounding the latter. These plates are margined with small granules. The majority of the small plates bear each a valvate, transversely elongated pedicellaria in the centre. The organ is often surrounded by coarse granules usually larger than marginal ones. The pedicellariae are 
scarce in the large plates, and there is found a central group of spaced granules, which when removed leave circular pits behind them. The central granules vary in number from 1 to 13 according to the size of plates. Papulae single, situated between the plates, distributed all over the surface.

Superomarginal plates very prominent, 10 in number, with convex outer surface rounded. These in interradial portion are coincident with the inferomarginals in position, but in the outer half of ray the two plates alternate. The superomarginals are higher than long and nearly as wide as long in interradial portion, then become wider than long distad. The plates are each margined with a single row of closely arranged small granules, and the entire surface bears uniformly spaced coarse granules. There are, besides, large valvate pedicellariae along the lateral surface of the plates, 1 or 2 for a plate, but the organ is absent from the distal 3 or 4 plates. The pedicellariae are similar in form to those of dorsal plates. Inferomarginal plates closely similar to the superomarginals in all respects.

Ventrolateral plates closely set to one another, mostly subpentagonal in form. These are arranged in fairly regular longitudinal series, though being a little irregular in the portion adjacent to mouth plates, where small secondary intermediate plates are placed between them. Almost all the plates are each armed with a large valvate pedicellaria. The organ is encircled by 10 or more granules various in size. "Those 3 or 4 facing the outer face of valve are much enlarged and compressed. A few additional smaller granules are placed at the outer side of the large granules, but most of the plates lack the secondary granules. The pedicellariae are usually single in Goto's description, but in the present specimen 2 pedicellariae occur in the plates adjacent to adambulacral plates. When 2 pedicellariae present, one of them is much smaller, about half as large as the other.

Adambulacral plates wider than long in the proximal portion of ray, squarish in the distal half. The armature is composed of 2 or 3 stout, flattened, bluntly pointed furrow spines. When 3 spines present, the adoral one is smaller and shorter than the others. Behind the furrow series stands a stouter but shorter subambulacral spine. When there are 2 spines, the adoral one is much smaller. Next follows a row of 2 large conico-elliptical spines or granules. Besides these, 3 or 4 small granules are placed along the transverse margin of the plate, and those on the outer margin are scarce. The armature of mouth plates consists of a series of stout, long, compressed 5 or 6 furrow spines. The one at the mouth end is thicker and longer than the others, the remainder rather regularly graduated, and the outermost much smaller. On the surface of the plate are 2 suboral spines parallel to the furrow series. On the rest of the surface are several granules various in size. 
Madreporite circular in form, slightly smaller than the large dorsal plates, situated nearer the centre of disc than the margin.

Loc. Kii.oshima, depth unknown.

\section{Lithosoma japonica sp. nov.}

(Pl. VIII, Figs. 6, 7, 8, 9)

The writer examined two specimens belonging to Goniasteridae. The specimens agree with Lithosoma, a deep-sea form of the Philippine Isiands, in general respects, though rays are not long and slender, but short, and small spatulate excavate pedicellariae absent from dorsal surface. The Japanese specimens may be referred to a new form of Lithosoma. The measurements: are as follows:

\section{$R$}

$33 \mathrm{~mm}$

$24 \mathrm{~mm}$ $r$

$17 \mathrm{~mm}$

$12 \mathrm{~mm}$
$\mathrm{R}: \mathrm{r}$

1.9

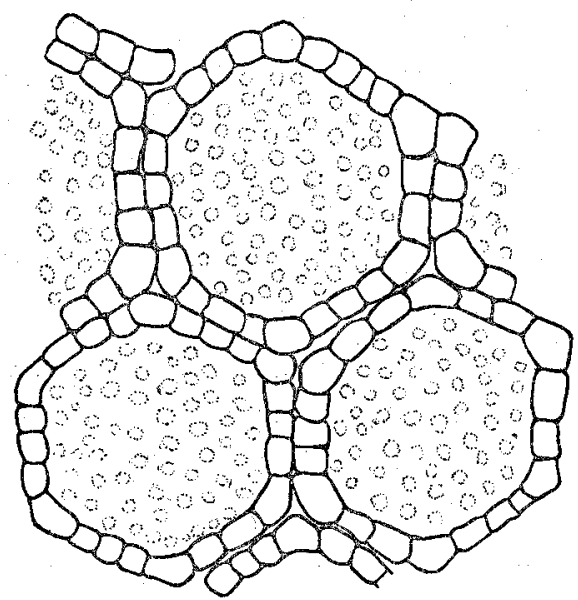

Fig. 2. Tithosoma japonica: Dorsal plates in the radia! portion, $25 \times$.

Breadth of ray at base in the large specimen measures $20 \mathrm{~mm}$, at $3 \mathrm{rd}$ superomarginal plates $12 \mathrm{~mm}$.

Dorsal area stellato-pentagonal. Dorsal plates hexagonal in form, arranged in regular radial and parallel series, the surface being smooth, bearing numerous uniformly spaced minute blister-like bosses. Those of the mid radial 
series are very slightly larger than the neighbours, but never conspicuously. All the plates are bordered by a single complete series of flat immersed granules squarish or oblong in form. No secondary smaller intermediate plates. Papulae 6 about a plate, 1 for each comer of plate, but absent in interradial areas. No pedicellariae in corsal plates. When viewed from coelomic side, the dorsal plates are hexagonal with somewhat truncated corners and the surface convex. In interradial areas lacking papulae the plates fit tightly together.

Marginal plates massive, wicler than long, and the surface swollen. Supermarginal plates 9 in number, and beyond the 4 th these are in contact with each other alternately along radial median line. The first plates are slightly smaller than the following 3 or 4 , the 3 rd or 4 th being most massive, then gradually decreasing in size toward the tip of ray. The surface of the plates is smooth, but numerous minute hyaline bosses are scattered uniformly on the dorsal side. These are more spaced and inconspicuops than those on the dorsal plates, and become gradually indistinct tow ard the lateral side of plate. Marginal granules small, mostly oblong. Tiny 2-jawed entrenched spatulate pedicellariae, if present, occur along the transverse margin of the plate or the outer margin, 1 or 2 for a plate. The base of each jaw is about half as wide as the length. Inferomarginal plates correspond to the superomarginals in position, the first plates being smaller than the following 2 or 3 as in the superomarginals. No hyaline bosses on the surface. In the smaller specimen at the writer's hand the hyaline bosses are absent from the surface of the marginals, the occurrence of the bosses, therefore, seems to be an unreliable feature to classify the present group, especially in unmatured specimens.

Ventrolateral plates slightly swollen, with minute hyaline bosses on the surface, arranged in relatively regular chevrons. These are regular or less regular 4 -sided, and the series next to adambulacral plates extending beyond the middle of R. Small entrenched pedicellariae occur in the series, mostly 1 for a plate, rarely 2 . The marginal granules are more distinct than in marginal plates.

Adambulacral plates each with an angular furrow face deep in furrow, the aboral facet of the apophysis being concave and longer than the adoral which is slightly concave or nearly straight. The first 3 or 4 plates each with a shallow angle. The apophysis is more angular in the smaller specimen, separating the consective pairs of tube-feet. Furrow comb consisting of proximally 5 or 6 , further along ray 7 to 9 subequal robust spines, the mesials being prismatic or flattened with edge to furrow. The most aboral ones are 
much thicker and broader than the mesials, with side to furrow, about twice as wide as the latter.

In the smaller specimen the furrow comb consists of 5 or 6 blunt, more or less compressed spines, the distalmost being the broadest. There is a distinct interval without spines on the aboral facet of the apophysis, and the enlarged spine is separated from the rest.

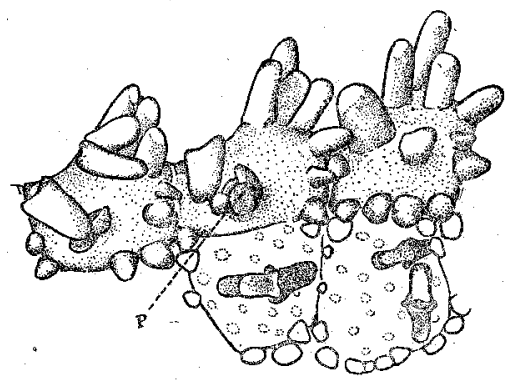

Fig. 3. Lithosoma japonica: Adambulacral plates and the ventrolaterals in the specimen $(R 24 \mathrm{~mm})$, the right ones being the 6 th, $15 \times$; p. pedicellaria with 4 valves.

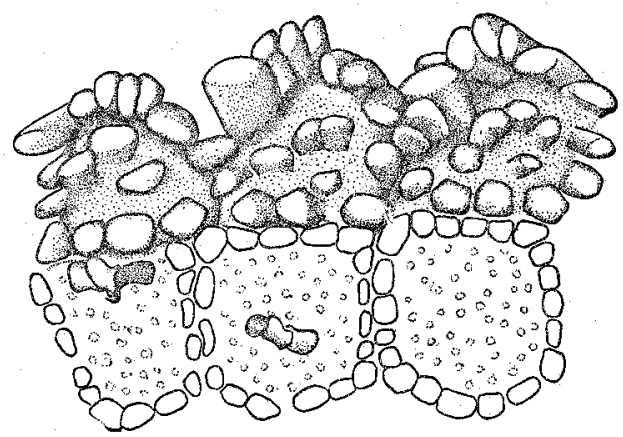

Fig. 4. Lithosoma japonica: Adambulacral plates and the ventrolaterals in the specimen ( $R 33 \mathrm{~mm}$, the right ones being the 5 th, $15 \times$.

The border of plates is beset with a row of 6 to 8 subequal subconical granules, and the surface with 2 to 5 granules forming more or less a longitudinal series spaced from the furrow comb. In the smaller specimen the marginal granules are fewer, and the granules on the surface are mostly replaced by a pedicellaria with 2 to 5 broad jaws.

Mouth plates small, rather evenly triangular, the straight furrow margin bearing 6 or 7 spines. The innermost spine is enlarged, heavy, four-sided, the rest compressed, prismatic, round-tipped, and the outermost one flattened, a little enlarged. Seven or 8 suboral granules situated along the median suture 
line, and the inners prismatic or four-sided. Between the series and the furrow are 3 to 5 granules.

Madreporite small, flat, hexagonal surrounded by 6 plates, with coarse irregular ridges radiating from the centre, situated about one-third the distance from the centre of disc to the margin. In the smaller specimen the madreporite is surrounded by 5 plates.

Loc. Kii-oshima, depth unknown.

\section{Anthenoides epixanthus (FISHER)}

(P1. VIII, Figs. 10, 11)

Antheniaster cpixanthus: FISHER, 1906, p. 1057, pl. 20, fig. 3; pl. 26, figs, 1, 1a-c; pl. 29, figs. 1,$2 ;$ pl. 49 , fig. 1 .

The present species has previously been reported only from the Hawaiian Islands, from 178 to 267 fathoms in depth. The writer examined 2 specimens closely related to the species. They are probably a young, slenderrayed form of the species, though differing from which in having thin membrane. The measurements are as follows :

$\begin{array}{ccc}\mathrm{R} & \mathrm{r} & \mathrm{R}: \mathrm{r} \\ 42 \mathrm{~mm} & 17 \mathrm{~mm} & 2.5 \\ 36 \mathrm{~mm} & 14 \mathrm{~mm} & 2.6\end{array}$

Body flat and depressed. Disc large, pentagonal in form, slightly inflated. Rays tapering, short and slender. Interbrachial arcs rounded. The dorsal surface is overlaid by an exceedingly thin membrane, which in drying allows microscopic granules to be seen. The granules are subequal in size, scattered all over the surface, but closely placed in interradial areas, where these are uniformly scattered, 30 or more for a plate.

Do: sal plates hexagonal in form, arranged in regular series, the radials being wider than long. Intermediate plates poorly developed in either side of the radial median. Papulae confined to radial regions, 1 for each corner of plate. No pedice lariae in dorsal surface.

Superomarginal plates 15 in number, opposite to each inferomarginal plate in position, gradually decreasing in width toward the tip of ray. About 5 proximal plates have spaced coarse granules in the centre and microscopic granules surrounding them. The coarse granules are 9 or 10 in number in the frst plate, 4 or 3 in the $4 \mathrm{th}$, and these are absent from the outer half of ray. Terminal plates pentagonal in form, longer than wide, with 5 spinelets, 3 of which being a little prominent. Inferomarginal plates wider than long, de- 
creasing regularly in size distad and more massive than the superomarginals. The granulation of these plates is similar to that of the superomarginals but the granules are slightly coarser than the latter. The coarse granules are found along the edge of ray, but absent from the outer half.

Ventrolateral plates slightly tumid, arranged in chevrons, decreasing in size toward the margin of disc, each with 1 to 7 unequal, spaced large subhemispherical granules surrounded by 8 to 18 spaced small granules. Some of them adjacent to mouth plates bear 2-jawed pedicellariae, 1 for a plate. The jaws rarely 3.

Adambulacral plates longer than wide, with slightly curved furrow margin, each bearing a comb of 6 or 7 a little divergent, slender, slightly compressed, bluntly pointed furrow spines webbed for half their length. The mesial spines are longer than the laterals. Along middle of plate are a small bluntly pointed, subconical spine and 2 or 3 coarse granules. The spines are heavier but shorter than the furrow spines and gradually become long and stout toward the distal portion of ray. Between both the series, near the adoral margin of plate stands a rather slender 2 -jawed, narrowly spatulated pedicellaria. The pedicellariae occur in the first 1 or 2 plates and absent in the remainder.

Mouth plates slightly convex, each with' 8 or 9 oral spines, the inner 3 or 4 being enlarged and strongly compressed. Suboral armature composed of 3 or 4 short suboral spines and small spaced granules and in addition to these a pedicellaria, if present.

Madreporite flat, subcircular in form, situated a little nearer the centre of disc than the margin.

Gonads arranged in a compact series on either side of and parallel to interbrachial septum.

Loc. Off Minabe, depth $100 \mathrm{~m}$ and Oshima, depth unknown.

\section{Nardoa tuberculata GRAY}

Nardoa tuberculata : FISHER, 1919, p. 384, pl. 110, fig. 1; HAYASHI, 1938, p. 430, pl. 3, figs. $1,2$.

The tropical sea-star has not previously been recorded from Japan. A single specimen of the present species was examined, measuring $40 \mathrm{~mm}$ in $R$, $10 \mathrm{~mm}$ in $\mathrm{r}$. It seems to be a young form. The young form of $N$. tuberculata is very difficult to distinguish from $N$. tuberculata forma obtusa in the Ryukyu Islands, but the specimen examined has gradually tapering rays, thus the identification. 
Loc. Kii-oshima.

\section{Ophidiaster cribrarius LÜTKEN}

Ophidiaster cribrarius: HAYASHI, 1938, p. 64, pl. 4, figs. 7-13.

The present species has previously been recorded from the Ogasawara Islands and Amakusa, Kyusyu in Japan. A single 2-rayed specimen was examined, measuring $16 \mathrm{~mm}$ to $53 \mathrm{~mm}$ in $R, 7 \mathrm{~mm}$ in $\mathrm{r}$. The rays are various in length, the two being short.

Loc. Kii-oshima.

\section{Henricia Ohshimai forma acutispina $\mathrm{H}_{\mathrm{AYASHI}}$}

Henrieia Ohshimai forma acutispina: HAYASHI, 1940, p. 158, pl. 10, figs. 5, 6.

A single specimen of Henricia was examined, measuring $35 \mathrm{~mm}$ in $\mathrm{R}, 8$ $\mathrm{mm}$ in $\mathrm{r}$. It seems to be a form of the present species recorded by the present writer ('40) from Kii Channel, depth $200 \mathrm{~m}$ and off Rebun Is., depth 142 fathoms.

Second ventrolateral series present, reaching about half the length of ray, each with 2 to 5 spinelets. Adambulacral armature composed of 5 to 7 long slender spines, and furrow spines single.

Loc. Kii-oshima, depth $300 \mathrm{~m}$.

\section{Henricia pacifica HAYASHI}

Henricia pacifica: HAYASH, 1940, p. 152, pl. 9, figs. 7-10.

A single specimen of slender-rayed Henricia was examined. It measures $40 \mathrm{~mm}$ in $\mathrm{R}, 7 \mathrm{~mm}$ in $\mathrm{r}$. The example is referable to the present species collected by Soyo-maru'from off Goto Is., off Seto and Tsugaru Strait, depth $200 \mathrm{~m}$.

Loc. Kii-oshima, depth $300 \mathrm{~m}$.

\section{Henricia pachyderma HAYASHI}

Henricia pachyderma: HAYASHI, 1950, p. 160, pl. 7, figs. 1, 2 
Five specimens of Henricia were examined, which are considerably in unfavourable condition. Judging from the skeletal structure, these specimens seemingly belong to the present species. The measurements are as follows:

$\begin{array}{cccc}R & r & R & r \\ 36 \mathrm{~mm} & 8 \mathrm{~mm} & 42 \mathrm{~mm} & 10 \mathrm{~mm} \\ 40 \mathrm{~mm} & 10 \mathrm{~mm} & 43 \mathrm{~mm} & 10 \mathrm{~mm} \\ 40 \mathrm{~mm} & 9 \mathrm{~mm} & & \end{array}$

Loc. Off Minabe, depth 100-200 m.

\section{Solaster Uchidai HAYASHI}

Solaster Uchidai: HAYASHI, 1939, p. 306, pl. 24, figs. 3, 4; HAYASHI, 1940, p. 184.

A single specimen of Solaster was examined, measuring $80 \mathrm{~mm}$ in $\mathrm{R}, 33$ $\mathrm{mm}$ in $\mathrm{r}$, rays 11 in number. It is a typical form of the present species distributing in the north Pacific coast of Honsyu, Japan.

Loc. Probably Kii-oshima.

\section{Coronaster volsellatus (SLADEN)}

(P1. VIII, Figs. 12, 13, 14)

Asterias (Stolasterias) volsellata: SLADEN, 1889, p. 584, pl. 107, figs. 1-4.

Heterasterias volsellata: VERRILL, 1914, pp. 27, 47.

Coronaster volsellatus: FiSHER, 1917, p. 25; FISHER, 1919, p. 496, pl. 135, figs. 4, 4a; pl. 151, figs. 2, 2a-c.

The present sea-star has not previously been recorded from the Japanese waters, but only from the Philippine Is. The specimens examined are

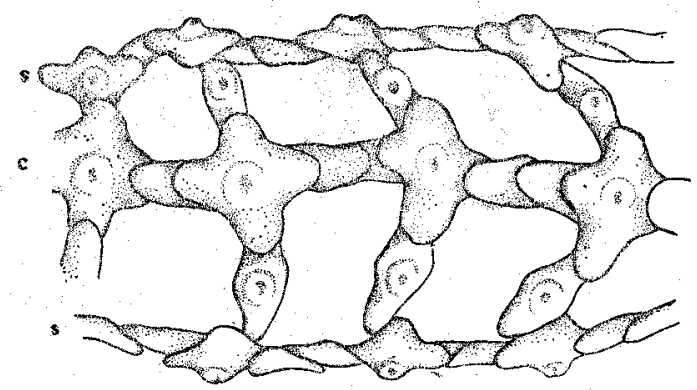

Fig. 5. Coronaster volsellatus: Skeletal structure in the proximal portion of ray, $5 \times ; c$ carinal series, s superomarginal series. 


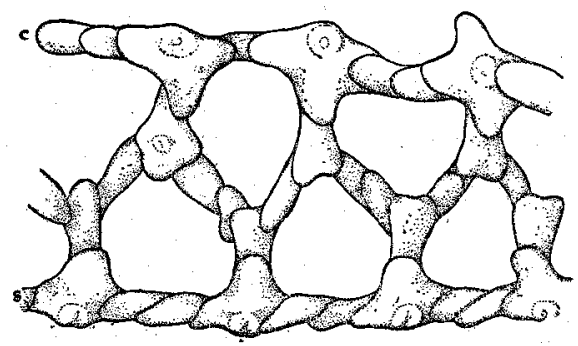

Fig. 6. Coronaster volsellatus: Skeletal structure in the proximal portion of ray, $5 \times$; c carinal series, a superomarginal series.

certainly referable to the present species. Four specimens were examined. In the two, all the rays are separated from disc. In the other two, some of the rays are disjointed. The joint of rays to disc may be fragile. One of them measures 56 to $82 \mathrm{~mm}$ in $R, 7.5 \mathrm{~mm}$ in $\mathrm{r}$, the other 69 to $70 \mathrm{~mm}$ in $\mathrm{R}, 7$ $\mathrm{mm}$ in $\mathrm{r}$. $\mathrm{R}$ ranging from $10 \mathrm{r}$ to $11 \mathrm{r}$.

Disc small, circular, the dorsal surface being nearly flat. Rays long and slender, 10 to 11 in number, more or less narrowed near the base.

Dorsal integument thin. Dorsal skeleton widely meshed, the mesh being more or less irregular, squarish or subpentagonal in form. Carinal plates arranged in a regular longitudinal series, composed of cruciform principal plates at each skeletal node and oblong connective ones, generally 1 or 2 in each interval. Carinal spines slender and acute, 1 for each principal plate, $3-3.6 \mathrm{~mm}$ in length. Dorsolateral skeleton composed of elongated plates interpolated between carinal plates and the superomarginals, 1 for each interval. The dorsolateral papular areas, therefore, are more or less quadrate in form. The skeletons, however, often form a mesh, and the papular areas are subpentagonal in form. Dorsolateral spines similar to the carinals in size and form, but slightly more slender. The spines are $2.7-3.7 \mathrm{~mm}$ long.

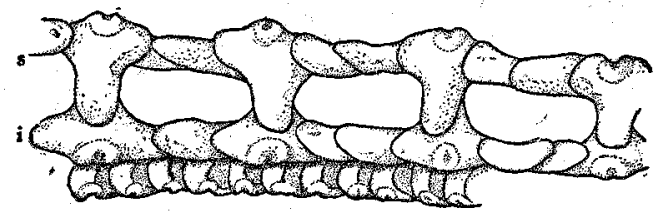

Fig, 7. Coronaster volsellatus: Skeletal structure in the proximal portion of ray, $5 \times$; i inferomarginal series, $s$ superomarginal series. 
Superomarginal plates cruciform, the lower lobes overlapping to each inferomarginal plate. The superomarginals are each joined by oblong intermediate plate, generally 2 in each interval. Inferomarginal plates corresponding to the superomarginals in position, each connected by 2 or 3 intermediate oblong plates. Intermarginal papular areas large, rectangular in form. Marginal spines slender and acute, one for each principal plate. Inferomarginal spines slightly longer than the superomarginals, measuring $3.6-4.1 \mathrm{~mm}$ in length at the proximal portion of ray.

Dorsal and marginal spines thickly encircled by a large number of small crossed pedicellariae born upon a heavy sheath. The crossed pedicellariae in dorsal spines measure 0.26 to $0.3 \mathrm{~mm}$ in length, and those of marginal spines are slightly smaller, 0.2 to $0.27 \mathrm{~mm}$ in length. Each lateral tooth of the jaws is enlarged, but the one a little smaller than the other. Small straight pedicellariae scattered all over the surface, measuring about 0.46 to $0.56 \mathrm{~mm}$ in

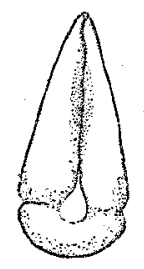

A
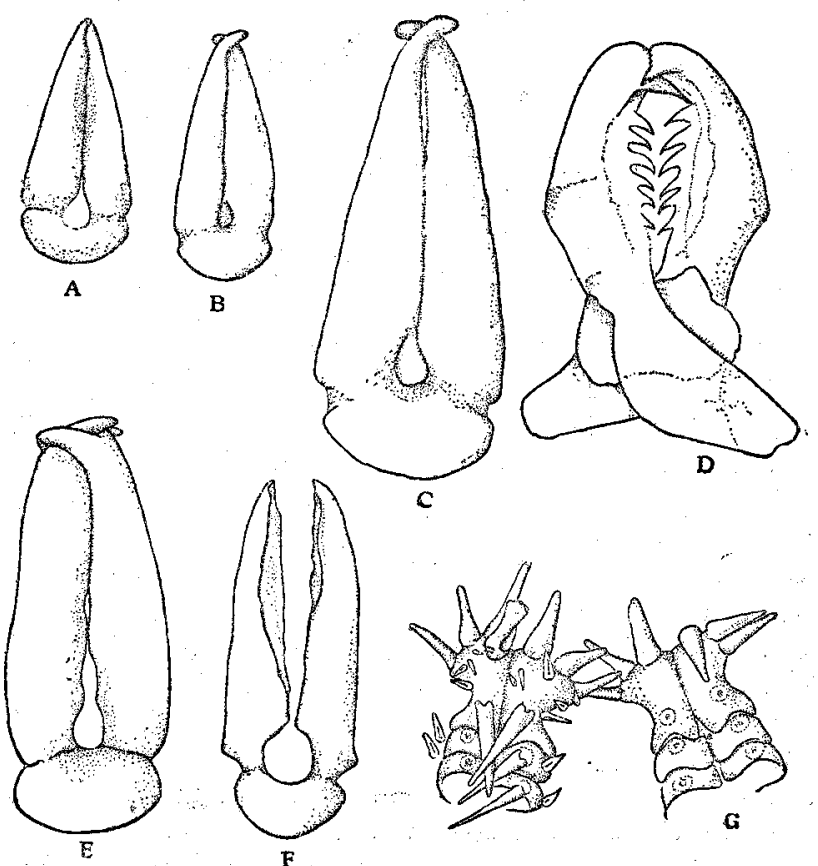

Fig. 8. Coronaster volsellatus: (A) straight pedicellaria in furrow, $85 \times$; (B) straight pedicellaria in furrow, $85 \times$; (C) straight pedicellaria in furrow, $65 x$; (D) dorsal crossed pedicellaria, 140X; (E) large straight pedicellaria in mouth plate, $35 \times$; (F) straight pedicellaria in dorsal papular area, $65 \times$; (G) ventral view of mouth plates and adambulacraI plates, $5 x$. 
length. Large unguiculate pedicellariae found in the mouth plates, 1 or 2 for a plate. The large ones are about $1.2 \mathrm{~mm}$ long.

Adambulacral plates small, band-like, separated by an interval being slightly wider than the length. Adambulacral spines single, arranged in a series, about 1.7 to $2.0 \mathrm{~mm}$ long in the proximal portion of ray. The spines are slender and tapering, without attached pedicellariae. Along furrow are scattered small pedunculate straight pedicellariae. These are various in size, about 0.25 to $0.8 \mathrm{~mm}$ in length, and the jaw-tips of the large ones are slightly crossed. Mouth plates large, excavated for the first tube-feet. On the middle of the ventral surface stands a stout cylindrical suboral spine, about $2 \mathrm{~mm}$ long, the base being more or less compressed. Oral spines 2 (3) for a plate, the inner one being similar to suboral spine in size and form, but the base more compressed. The outer ones are smaller than the inner, about half as large as the latter. There are no conspicuous streamers of straight pedicellariae at the base of spines.

Madreporite circular in form, situated nearer the margin of disc than the centre.

Loc. Kii-oshima.

\section{LITERATURE CITED}

FISHER. W. K. 1906. The Starfishes of the Hawaiian Islands. U. S. Fish. Commission Bulletin for 1903, pt. iii, p. 987-1130, 49 pis.

26. 1917. The Asteroid Genus Coronaster. Proc. Biol. Soc. Washington, vol. 30, pp. 231919. Starfishes of the Philippine Seas and Adjacent Waters. Smiths. Inst. U.S. Nat. Mus., Bull. 100, vol. 3, 712 pp. 156 pls.

Goto, S. 1914. A Descriptive Monograph of Japanese Asteroidea. J. Coll. Sci. Imp. Univ. Tokyo, vol. 29 , art. 1 , pp. 1-808, 19 pis.

HAYASHI, R. 1938a. Sea-gtars of the Ogasawara Islands. Annot. Zool. Japon., vol. 17, pp. $59-68,1 \mathrm{pl}$.

1938b. Sea-stars of the Caroline Islands. Palao Trop. Biol. Station Studies, vol. 1, no. 3 , pp. $417-446,3$ p's.

1938c. Sea-stars in the Vicinity of the Seto Marine Biological Laboratory. Bull. Biogeogr. Soc. Jap., vol. 8, pp. 271-292, 3 pls.

1939. Solasterids in Japanese Waters. J. Fac. Sci. Hokkaido Imp. Univ., ser. 6 , Zool., vol. 6 , pp. $297-311,2$ pis.

1940. Contributions to the Classification of the Sea-stars of Japan, I. Spinulosa. J. Fac. Sci. Hokkaido Imp. Univ., ser. 6, Zool., vol. 7, pp. 107--204, 7 pls.

1943. Contributions to the Classification of the Sea-stars of Japan, II. Forcipulata, with the Note on the Relationship between the Skeleta! Structure and Respiratory Organs of the Sea-stars. Ibid., vol. 8, pp. 133-281, 11 pls.

SLADEN, W. P. 1889. Report on the Asteroidea collected by the H. M. S. Challenger. Zoology, vol. 30 , xliit 893 pp., 117 pis., 1 chart.

Verrill, A. E. 1914. Monograph of the Shallow-water Starfishes of the North Pacific Coast from the Arctic Ocean to California. Smiths. Inst. Harriman Alaska series, vol. 14, 2 parts, xii 408 pp., 110 pis. 


\section{EXPLANATION OF PLATE VIII}

Fig. 1. Hippasteria imperialis; dorsal side. About $2 / 3 \times$.

Fig. 2. Hippasteria imperialis; ventral side. About $2 / 3 \times$.

Fig. 3. Mediaster brachiatus; dorsal side. About $4 / 5 \times$.

Fig. 4. Mediaster brachiatus; ventral side. About natural size.

Fig. 5. Nardoa tuberculata; dorsal side. About $2 / 3 \times$.

Fig. 6. Lithosoma japonica n. sp.; ventral side. About $3 / 4 \times$.

Fig. 7. Lithosoma japonica n. sp.; dorsal side. About $3 / 4 \times$.

Fig. 8. Lithosoma japonica n. sp.; ventral side. About $3 / 4 \times$.

Fig. 9. Lithosoma japonica n. sp.; dorsal side. About $3 / 4 \times$.

Fig. 10. Anthenoides epixanthus; dorsal side. About $2 / 3 \times$.

Fig. 11. Anthenoides epixanthus; ventral side. About $2 / 3 \times$.

Fig. 12. Coronaster volsellatus; dorsal side. About natural size.

Fig. 13. Coronaster volsellatus; ventral side. About $2 / 3 \times$.

Fig. 14. Coronaster volsellatus; ventral side. About $2 / 3 \times$. 
Publ. Seto Mar. Biol. Lab., II, 2 (1952)

PLATE VIII

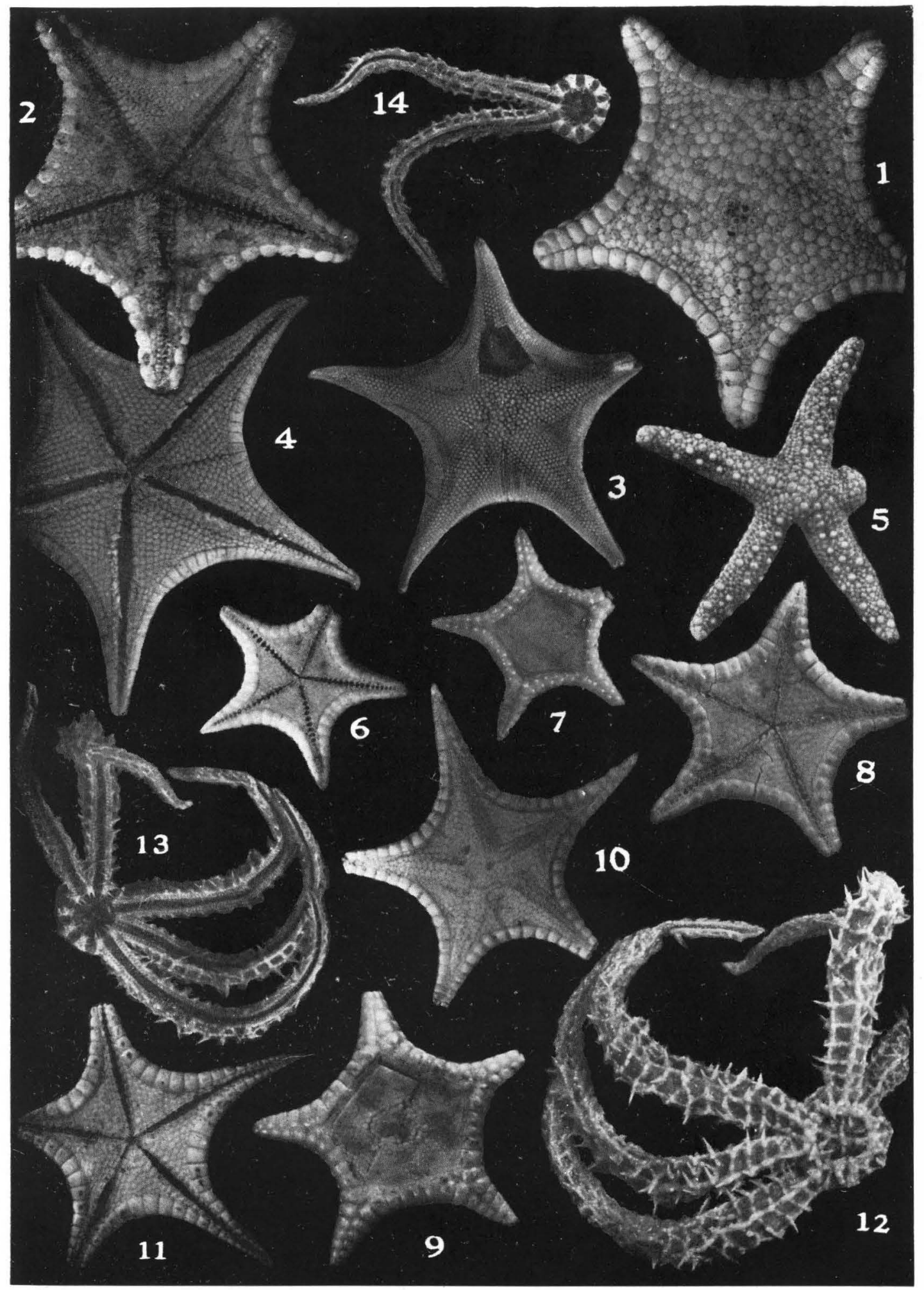

R. Hayashi: Sea-Stars of Seto and Adjacent Waters. 